\title{
Indonesian Sub-Majors at Chinese Universities and Belt and Road Initiative (BRI)
}

\author{
Isyana Adriani \\ School of International Relations, President University \\ Isyana.adriani@president.ac.id
}

\begin{abstract}
Abstrak
Sejak Presiden Cina Xi Jinping memperkenalkan mega proyek infrastruktur Belt and Road Initiative (BRI) pada akhir 2013, banyak yang meragukan tujuan utama tujuan Presiden Xi dengan mega proyek itu, terutama sejak Presiden Amerika Serikat (AS) Donald Trump mulai berkuasa pada Januari 2017 dan sampai saat ini tidak memiliki kebijakan luar negeri yang jelas terkait kawasan Asia Pasifik. BRI, yang berencana meaghubungkan Cina dengan semua benua di Cina, sudah memiliki dampak positif dan negatif di berbagai belahan dunia. Salah satunya di Afrika, dimana Cina membantu pembangunan Trans-African Highway yang sudah direncanakan sejak 1971. Tapi dampak negatifnya adalah hutang negara-negara Afrika ke Cina melonjak berkali lipat, dan bukan tidak mungkin mereka akan mengalami apa yang dialami Sri Lanka, yang harus merelakan Beijing mengambil alih Pelabuhan Hambantota. Di Indonesia sendiri, sudah ada beberapa proyek BRI, diantara Kereta Cepat Indonesia Cina (KCIC) Bandung-Jakarta dan Morowali Industrial Park di Sulawesi Tengah. Masyarakat Indonesia resah karena bisa jadi proyek-proyek ini merupakan "debt trap" seperti yang terjadi di Afrika dan Sri Lanka, sementara jumlah tenaga kerja asing dari Cina terus melonjak, mengancam ketersediaan lapangan kerja bagi Warga Negara Indonesia (WNI). Tapi di sisi lain, keikutsertaan Indonesia mendongkrak pentingnya Indonesia bagi Cina, yang dapat dilihat antara lain dari bertambahnya jumlah universitas di Cina yang membuka sub-jurusan bahasa dan budayaan Indonesia selama tujuh tahun terakhir. Esai ini berfokus pada bagaimana sub-jurusan bahasa dan budaya Indonesia di universitas-universitas di Cina memberikan kontribusi bagi BRI di Indonesia.
\end{abstract}

Kata kunci: BRI, Xi Jinping, Cina, Indonesia, universitas, sub-jurusan bahasa dan budaya Indonesia

\begin{abstract}
Since President of China Xi Jinping introduced the mega infrastructure project Belt and Road Initiative (BRI) in late 2013, many have doubted the real objective of the president, particularly since world leadership position has been vacant because US President Donald Trump still has no clear foreign policy on Asia Pacific. BRI, which aims to connect China to all continents in the world, has already had negative and positive impacts. One of which is Africa, where China has been
\end{abstract}


helping the Trans-African Highway project, a project that has been planned since 1971. However, BRI has caused African countries' debts to China to multiply, and it is not impossible that they will experience what Sri Lanka has already experienced: Beijing taking over their Hambantota Port. In Indonesia itself, there have been several BRI projects, such as the 142-km fast train that connects Bandung, West Java, to Jakarta, and Morowali Industrial Park in Central Sulawesi. However, despite BRI's help with infrastructure many people are suspicious that Indonesia will fall into a "debt trap" like Sri Lanka and African countries already did. They are also worried about the ever-increasing number of Chinese workers to Indonesia, which threaten the availability of jobs for locals. On the other hand, Indonesia's involvement in BRI shows that Indonesia is an important country to China, and this can be seen through many things, one of which is the growing number of Chinese universities having Indonesian language and culture submajors in the past seven years. This essay focuses on how these Indonesian language and culture sub-majors contribute to the success of BRI in China.

Keywords: BRI, Xi Jinping, China, Indonesia, universities, Indonesian language and culture sub-majors

\section{Introduction}

People's Republic of China (henceforth referred to as China) and Indonesia's diplomatic relations have been going on for 58 years as of 2018, albeit with a stop that spanned 23 years following China's application of Cultural Revolution. The relation resumed in 1990, and since then the two countries have witnessed significant milestones that happened in either country such as the fall of Indonesia's New Order regime in 1998 and the abolishment of One Child Policy in China in 2015.

Indonesia and China have signed many memorandums of understanding (MOU's) throughout their diplomatic relation in many fields including education. Several universities in Indonesia, such as Al-Azhar University in Jakarta and Malang Muhammadiyah University in Malang, East Java, partner with Confucius Institute, the Chinese cultural center that offers Mandarin trainings and facilitates exchange programs between Chinese and Indonesian students (Amelia \& Adriani, 2016). A few private universities in Indonesia have also signed MOU's with China's Ministry of Education to offer scholarships to underprivileged Chinese students to study in Indonesia. In China itself, as of December 2017 there have been 16 universities that teach Indonesian language and culture as sub-majors, and many have predicted that in the near future there will be more universities offering Indonesian language and culture studies (C. Anwar, personal communication, September 6, 2018).

This essay aims to probe into China's enthusiasm in opening Indonesian language and culture sub-majors at universities. It attempts to answer the question of how these Indonesian studies sub-majors at universities in China contribute to 
President Xi Jinping's global infrastructure project Belt and Road Initiative (BRI). It will take into consideration the Chinese government's view on Indonesia.

\section{Brief History of Ethnic Chinese in Indonesia and the Importance of China to Indonesia 1950-1998}

The diplomatic relation between Indonesia and China cannot be separated from the history of Chinese presence in Indonesia, long before the latter became an independent state. It is believed that earliest Chinese settlers in Nusantara, the name Indonesia was known as before colonization by the Dutch and Japanese, arrived in 1293 (Suryadinata, 1978). Throughout the following centuries, Chinese settlers and their descendants, most of whom are merchants, have experienced economic prominence, discrimination and massacres. Two most notorious massacres against ethnic Chinese in Indonesia (henceforth referred to as ChineseIndonesians) occurred in 1740 and 1998, where thousands of them were killed as victims of injustice by the ruling government (Suryadinata, 1978: 78-97). However, despite their colorful past, China and Indonesia began diplomatic relations on April 13 1950, and unlike other countries that had to acknowledge Indonesia's independence first, these diplomatic relations started without China publicly acknowledging the independence of Indonesia (C. Anwar, personal communication, September 6, 2018).

After the diplomatic relation started, universities in Indonesia opened Mandarin language and literature departments. For example, University of Indonesia, a prominent state university in the country, opened their Mandarin department in the early 1950s and soon gained popularity amongst students aspiring to be civil servants in the foreign affairs and immigration ministries. Indeed, Mandarin graduates were useful in the Soekarno administration, as President Soekarno was known for his involvement in the Jakarta-Beijing-Moscow-Pyongyang axis. This axis was very important for Soekarno in order to prove to the Western world amidst Cold War that Indonesia, despite its very young age, could not be easily persuaded to root for liberalism and capitalism. Instead, Soekarno warmly embraced the communist axis of Pyongyang, Moscow and Beijing which shocked United States of America (USA) and its allies. This move proved to be a success, and by the early 1960 s Indonesia was one of the strongest young states in the world (Dahana \& Herlijanto, 2018).

However, despite that success, Soekarno's alignment towards the left worried many in Indonesia. His close relations with Partai Komunis Indonesia (Indonesian Communist Party (PKI)) enabled the party to propose the establishment of the Fifth Force, a people's army modeled after Chinese People's Liberation Army, in 1964. Although this proposal was rejected by army head General Ahmad Yani, PKI was able to celebrate their 45th anniversary in a big way in August of the following year, with representatives of Vietnamese Communist Party in attendance. Earlier, in May of the same year, Soekarno held a celebration for the 10th anniversary of The Asia-Africa Conference and China's Prime Minister Zhou Enlai was in 
attendance. His presence there greatly attracted foreign and domestic press. To top it all off, then President of China, Liu Shaoqi, and China's Minister of Foreign Affairs Chen Yi came to attend the 20th anniversary of Independence Day ceremony on August 171965 which was held at the National Monument in Central Jakarta. According to Jusuf Wanandi in his book "Shades of Grey: A Political Memoir of Modern Indonesia 1965-1998" (2012: 35), it was the biggest Independence Day celebration in the history of Indonesia.

China and Vietnam were not the only communist countries enjoying close ties with Indonesia. Universities in East Germany generously distributed honorary doctorate degrees to many government officials in Indonesia (Wanandi, 2012). In addition to that, Soekarno was also famous for sending students to study in communist countries such as The Czech Republic (then Czechoslovakia), Russia and even Democratic People's Republic of Korea (DPRK). The first batch of these students left Indonesia in 1957 (Djamaluddin et al., 2002: 11).

October and September 1965 saw Soekarno being overthrown through a coup d'etat allegedly staged by PKI. This gave an opportunity for then General Soeharto to conduct a nation-wide hunt against anyone suspected of being members of even mere sympathizers of PKI, after having executed PKI leaders such as the party's chairman Dipa Nusantara Aidit. Soeharto's fight against anything pertaining to communism also extended to Indonesian students in DPRK and Soviet countries that his predecessor sent. These students returned to Indonesia upon finishing their studies, and merely on the baseless grounds of sympathizing with communism, Soeharto put many of them in jail without a trial. Some of them even had their passports confiscated by the Embassy of Indonesia while still overseas, leaving them stateless (Djamaluddin et al., 2002).

Soeharto was then sworn in as president in 1966 and even though he retained Soekarno's non-bloc foreign policy to stay neutral amidst the Cold War, he very much leaned towards the West. With this, China lost its foothold in Indonesia as Indonesia was not only a strong potential ally in communism, but also an important link to Union of Soviet Socialist Republics (USSR) and Western countries. This loss was one of the reasons China began Cultural Revolution also in 1966, which in turn led to its severance of diplomatic relations with Indonesia a year later (Dahana \& Herlijanto, 2018).

In keeping with swiping off all the things communism-related, by 1975 Soeharto had completely closed down all Mandarin-speaking schools by force (Sutami, 2007) and he also banned Chinese-Indonesians from observing their Chinese traditions such as celebrating Lunar New Year. To make matters worse, Soeharto refused to grant Indonesian citizenship to children born to Chinese-Indonesian couples who inherited naturalized Chinese citizenship from their ancestors, but could not make China their home because they had been in Indonesia for generations. As a result, many Indonesian-Chinese children were barred from tertiary education and healthcare (Sutami, $\mathrm{H}, 2007$ : 222-237). This, however, did 
not deter Indonesian youth's interest in learning Mandarin. This determination to learn Mandarin very likely stemmed from exposure to Chinese culture brought by Hong Kong and Taiwanese show business. For example, in 1971 the Taiwanese movie "The Magnificent Chivalry" was promoted in a massive way in Indonesia. In the early to the middle of 1990s, Hong Kong and Taiwanese television series such as "White Snake Legend" enjoyed huge popularity as they were aired on local television channels on a weekly basis (Dahana \& Herlijanto, 2018).

That was just on the general public's part. After the Soeharto administration reopened diplomatic relations with China in 1990, his government treated China as an important partner. In July 1985, five years before diplomatic relations were reestablished, Kamar Dagang Indonesia (The Indonesian Chamber of Commerce (KADIN)) and The China Council for The Promotion of International Trade (CCPIT) signed an MOU for the re-establishment of a direct trade link between the two countries, as at that time both China and Indonesia were struggling to attract export markets in USA, Japan and European Union (EU) countries. Prior to the signing of the MOU, in the early 1980s, there had been discussions between Indonesian and Chinese scholars about the importance of an economic relation as the most logical step to re-start a full diplomatic relation. Chinese scholars even saw the re-establishment of a diplomatic relation with Indonesia as a significant step to start relations with other countries in the Pacific region. All these were made possible by the death of Chairman Mao Zedong in 1976 and the current regime at that time which more openly embraced market economy. This regime, under the leadership of President Deng Xiaoping, ushered China into an economic reformation to overcome hunger and attract foreign technology in 1978, covering rural and urban areas (Atje and Gaduh, 1999).

Another logical reason for China to set up a direct trade link with Indonesia, other than Indonesia's role as a hub to other Pacific countries, was the economic boom in the country. Due to an upsurge in oil prices in the period of 1973-1981, Indonesia was able to get up to 75 per cent of export earnings from the oil and gas sector, as well as 70 per cent of the government budget revenues. This increased the level of confidence in investors and Indonesia could secure loans with favorable terms from global finance institutions such as the World Bank and Inter-Government Group for Indonesia (IGGI) member countries (Atje and Gaduh, 1999).

Apart from economic aspects, China also highly regarded Indonesia's geographical conditions and relations with other countries especially its membership in Association of Southeast Asian Nations (ASEAN), which Indonesia co-founded in 1967. Indonesia has always been rich with natural resources and with a population of nearly 200 million at that time, which mostly consisted of young people, Indonesia had an abundance of potential. China's confidence about Indonesia's significant role as a hub to other Pacific countries was proven when Singapore as another ASEAN member state normalized its relation with China after Indonesia had done the same (Atje and Gaduh, 1999). 
The government of Indonesia also had their own reasons behind said MOU signing. First of all, Indonesia believed that it was just a matter of time until China became a super power, especially after it successfully ousted Taiwan from the United Nations (UN) in 1971 in a bid for the enforcement of One China Policy. This prediction halfway came true when, by 1997, China's Gross Domestic Product (GDP) reached US\$901 billion by official estimation with a total export value of US\$ 182.7 billion. On the other hand, Indonesia's GDP in the same year only reached an official estimation of US\$204 billion and an export value of US\$56 billion (Asia Pacific Economics Group, 1998 in Atje and Gaduh, 1999) The second reason was that Indonesia felt that with the post-Mao China, it could have a mostly economy-driven relation with government involvements being kept at a minimum. This is the kind of relation that Indonesia, even to date, has had with Taiwan and Hong Kong (Atje and Gaduh, 1999).

The third reason, which was arguably the most important, was that since Deng Xiaoping started economic liberalization in 1978 China had been attracting Foreign Direct Investments (FDI's) for a number of reasons, most notably its population which stood at 1.135 billion by 1990 (Peng, 2011). In that year alone, China received a US\$ 3.5 billion worth of FDI's or about 17.5 per cent of all FDI's to East Asia, whereas Indonesia only got a paltry US\$1.1 billion worth of FDI's. Fast forward to 1997, FDI's into China stood at US\$ 43 billion out of US\$ 83.5 billion worth of total FDI's that went to East Asia, and at the same time, Indonesia received a mere US $\$ 5.7$ billion of FDI's. This was the reason why in 1994, to face competition with China, Indonesian government issued a policy that enabled foreign investors to own 100 per cent of shares of the companies they opened in Indonesia (Atje and Gaduh, 1999).

Trade between China and Indonesia started from relatively small volumes, but gradually increased as time passed by. In the period of 1991-1998, Indonesia's non-oil and gas exports to China increased from around US $\$ 580$ million to US\$ 1320 million. Likewise, Indonesia's imports from China went up from about US\$ 800 million in 1991 to US\$ 1270 million in 1997 . The number then fell to US\$980 million in 1998 due to a severe economic crisis in Indonesia. Despite that, however, since the 1985 MOU of direct trade link, Indonesia's exports and imports to Chinese economies (China, Taiwan and Hong Kong) have enjoyed a steady increase (Atje and Gaduh, 1999).

Trade volumes between Chinese economies and Indonesia ended up being bigger than those between Indonesia and other ASEAN member states. In 1985, Indonesia's exports to and imports from ASEAN countries were 10.6 per cent and 9.4 per cent respectively out of the country's total exports and imports. In the same year, Indonesia's exports to and imports from Chinese economies accounted for 4.2 per cent and 5.7 per cent respectively out of Indonesia's total exports and imports. In a matter of 12 years, in 1997, these numbers grew to be 11.3 per cent and 9.7 per cent. This was bigger than the number of exports to and imports from 
ASEAN countries in the same year, which fell to 6.2 per cent and 6.7 per cent (Atje and Gaduh, 1999).

Towards the end of the New Order regime in the late 1990s, many predicted that trade and investment flows between Indonesia and China would remain low in the near future, but these flows would grow gradually matching both countries' economic and technological developments. However, it was noteworthy that trade and investments were not the only forms of economic relations especially after diplomatic relation had been officially re-established on August 8 1990. Other economic relations following normalization of diplomatic relation such as tourism needed to be promoted and developed as well (Atje and Gaduh, 1999).

In addition to the signing of direct trade link MOU between China and Indonesia and the eventual re-establishment of the two countries' diplomatic relation, there was plenty of Hong Kong and Taiwanese influence in Indonesia during the New Order regime (Atje and Gaduh, 1999). We have already mentioned the Hong Kong and Taiwanese entertainment mostly in the forms of movies and television programs that exposed Indonesians to Chinese culture. The following paragraphs discuss Indonesia's economic partnerships with Hong Kong and Taiwan during the Soeharto administration that indirectly shaped the teaching of Chinese language and culture in Indonesia.

Although Indonesia does not have a diplomatic relation to Taiwan due to China ousting Taiwan from UN and the implementation of One China Policy, Indonesia has strong economic and trade relations with Taiwan, which is represented by Taipei Economic and Trade Office (TETO.) These relations, which started upon the opening of TETO's Jakarta office in 1971, have seen Taiwan becoming one of the main sources of foreign investments in Indonesia, although according to Chen (1995) most Taiwanese ventures in Indonesia were Small and Medium Enterprises (SME's). With Hong Kong, which was for the majority of the New Order regime under the British Crown rule, Indonesia gained another main source of foreign investments. In fact, towards the end of the regime and amidst a severe monetary crisis, Hong Kong FDI's managed to stay put whereas other foreign investments, such as American clothing company JC Penney, fled Indonesia (Atje \& Gaduh, 2018).

This was where the need for people with good skills in Mandarin and any other Chinese dialect as well as good knowledge in Chinese culture flourished. Despite the bottled anger at being treated as second class citizens in spite of their major contribution to Indonesia's economy, Chinese-Indonesians enrolled in Chinese language and culture departments at universities to learn more about their heritage, but most importantly to earn a good living out of being in the line of corporate connections to China. Chinese-Indonesian youth were not the only ones doing it, but many non-Chinese-Indonesians did it as well (Dahana \& Herlijanto, 2018). 
Soeharto's New Order regime ended with massacres against Chinese-Indonesians that left many losing their lives and others fleeing Indonesia. However, less than two years after the May 1998 bloody end of New Order regime, in early 2000 President Abdurrahman Wahid issued a decree that finally allowed ChineseIndonesians to openly observe their culture. This brought the Indonesia-China relations to a whole new level never experienced before.

\section{China-Indonesia Relations in Education during the Abdurrahman Wahid Administration and Beyond}

It all started in September 1999, only a year and four months after Soeharto was overthrown after a 32-year rule. Indonesia held its first post New Order presidential election and Abdurrahman Wahid, a Muslim politician who had previously gained recognition as head of the country's biggest Muslim organization Nahdatul Ulama (NU), was elected president. Amongst Wahid's breakthroughs during his brief presidency (he was impeached in July 2001), his Presidential Decree no. 6 year 2000 that was issued in January 2000 was arguably the most famous. That decree replaced President's Instruction no. 14 year 1967 about the prohibition in using Chinese symbols and characters in public. With the end of that discriminatory regulation, Chinese-Indonesians could fully and openly observe their Chinese heritage and they were no longer seen only through their economic contributions (Kuncono, 2018).

Said President's Instruction no. 14 year 1967 also damaged the psyche of Chinese Indonesians. Since they were not allowed to openly celebrate their heritage and even forced to adopt Indonesian names, most of them felt they were second class citizens. Reports of Chinese-Indonesians being blackmailed by government institution employees in getting services or even rejected right away on the grounds that they were "not real Indonesian citizens" were rampant during the New Order era. Chinese entertainment imported from Hong Kong and Taiwan, though visible, was seen by some as second class entertainment, inferior to its local and Hollywood counterparts. To top it all off, there was a strong notion that Chinese-Indonesians were only acknowledged through their economic contributions as many of them owned major companies, such as the Riady family who owns Lippo Group (Kuncono, 2018).

Not only lifting the ban against the use of Chinese symbols and characters in public, Wahid also dissolved SK Mendagri No 477/74054/1978 (Decree of Minister of Domestic Affairs no. 477/74054 year 1978) that only recognized five religions: Islam, Hinduism, Buddhism, Christianity and Catholicism. Followers of Confucianism in Indonesia, who have been in the country since 1883 according to earliest records, had to put either Buddhism or Christianity as their religions in their citizen identity cards. Confucianism was later officially recognized in 2006. Although Confucianism was recognized as a religion during the Susilo Bambang Yudhoyono administration, it was Wahid who thoroughly supported Majelis Tinggi 
Agama Konghucu Indonesia (The Indonesian Supreme Council for Confucianism (MATAKIN)) since 1996 (Kuncono, 2018).

Wahid had his own reasons to legalize the use of Chinese attributes in public and help for the struggle for the recognition of Confucianism as a religion. In a seminar on the roles of ethnic Chinese that was held in West Jakarta on April 27 2002, the then newly impeached Wahid said that he did both to inspire more nationalism within Chinese-Indonesians, many of whom were successful business owners. At the seminar, he called for Chinese-Indonesian big business owners to help SME owners and to bear in mind that they owed their success to Indonesia as a whole. It was his subtle way to say he did all that to prevent Chinese-Indonesian money from going overseas, as during the May 1998 massacres many ChineseIndonesian fled the country not only bringing their families but also their fortunes. It was also Wahid's way to send a message to the world that Indonesia was not a nation on the edge rampant with human rights violations, especially after East Timor (now Timor Leste) conducted a referendum with the majority voting for separation from Indonesia, just shortly after Wahid's presidential inauguration in September 1999 (Kuncono, 2018).

Specifically to letting Chinese-Indonesians celebrate Lunar New Year, according to Head of Majelis Agama Konghucu Indonesia (Indonesian Confucian Council (MAKIN)) Surabaya, East Java, chapter Ongky Setio Kuncono (2012), Wahid understood that Lunar New Year was not a religious event and therefore people of all religions could celebrate it. Moreover, he also understood that Lunar New Year celebrations could actually attract foreign tourists, especially if celebrations were conducted in predominantly Chinese-Indonesian cities such as Singkawang in West Kalimantan. This could mean more income for Indonesia and as for Singkawang, it later proved to be a popular destination especially around the time of Lunar New Year, as flights and hotels are always fully booked by celebrants (Kuncono, 2018).

Acceptance for Chinese culture by the Indonesian government opened a wide path for more partnerships with China, particularly in the field of education. Starting in the Wahid presidency, Mandarin has become a compulsory subject at schools, although according to Sutami (2007) Mandarin teaching resumed shortly after the regime change in 1998. Still according to the University of Indonesia Mandarin professor, due to a very long ban against the use of Chinese characters at schools and in everyday life, as of the middle of the 2000s Mandarin-teaching in Indonesia was very much behind that of neighboring countries such as Singapore and Malaysia. There was a great lack of good-quality books, and post-New Order Mandarin teachers had no idea how to effectively teach the language. Therefore, to keep Mandarin-teaching running either as a university major, a compulsory subject at school or as an extra-curricular activity, a myriad of needs have to be fulfilled. These needs are for an on-going supply for good-quality textbooks, curriculum development, teacher trainings and facility maintenance (Sutami, 2007). 
On the university level, more universities - private and state - opened Chinese language and culture departments. For example, Bina Nusantara University opened its Chinese language and culture department in 2002 and Universitas Sumatera Utara (North Sumatra University (USU)) opened theirs in 2007. This is where partnerships in the field of education with China come along. On September 28 2007, then Ambassador of China to Indonesia Lan Lijun signed an MOU for the establishment of Confucius Institute, China's global cultural center. Confucius Institute was brought by the partnership between The Office of Chinese Language Council International (also known as Hanban) and The Jakarta Chinese Language Teaching Center, and it was to partner with a number of universities in Indonesia. The first Confucius Institute in the country, however, was not opened until 2011 on the Universitas Al-Azhar Indonesia (Al-Azhar University of Indonesia (UAI)) campus in Jakarta. Three years later, in 2014, Confucius Institute opened at Universitas Negeri Malang (Malang State University (UNM)) in Malang, East Java. Also in 2014, Confucius Institute sealed a partnership with another university in Malang, Universitas Muhammadiyah Malang (Malang Muhammadiyah University (UMM.)) To date, Confucius Institute has partnered with seven universities in Indonesia, covering not only Jakarta and East Java but also West Kalimantan, West Java and South Sulawesi (Amelia \& Adriani, 2016: 57).

Confucius Institute runs exchange programs for students and lecturers in China and Indonesia. They also hold competitions with prizes such as a summer course at a Chinese university and trainings for Mandarin teachers. In addition to that, Confucius Institute sends Mandarin teachers to any institution that offers Mandarin lessons. In short, Confucius Institute caters to an ever-growing demand for Mandarin speakers to work for Chinese companies (Amelia \& Adriani, 2016: 58).

Until the middle of the 2000s, China was known in Indonesia as a producer of counterfeit goods. However, that image gradually changed as Chinese brands opened in Indonesia offering goods, mostly automotive and electronic, that could compete with already famous brands such as Nokia, Apple and Samsung. For example, leading Chinese electronic brand Huawei opened in Indonesia in 2000, but it did not gain recognition in the country until it launched a series of mini portable modems in 2009. So far, Huawei has gained international recognition, not only in Indonesia, for the company ranked 228th in Global Fortune 500 in 2014, based on revenues of products sold in 170 countries. In accordance with a May 2018 data from The Embassy of China, as of late 2017 Huawei has worked together with 300 local subcontractors and more than 100 local channel partners. Its local staff employment rate reached 86 per cent after indirectly opening around 20,000 job opportunities. Through a variety of knowledge transfer programs, Huawei has sent 12,000 of its local engineers to its Research and Development (R\&D) center in Shanghai, and the company has also given internship opportunities to 3,000 Information and Communication Technology (ICT) students (China Embassy, 2018). 
There are many other major Chinese companies operating in Indonesia in the communication field but this paragraph will focus on Oppo, Xiaomi and Vivo, three companies that have been described by Forbes as "the big four Chinese companies" along with Huawei itself. Needless to say, said three companies are Huawei's biggest competitors in the quest of fully winning the huge Indonesian market. According to Cendrowski (2017), the big four have broken China's habitual move of aiming for middle-lower class markets with Huawei in the leading position as sales of Huawei device units reached US\$39 billion worldwide in the first half of 2016, a 40 per cent increase from the same time in 2015. Experts said that this success was attributed in no small part to more advanced storefronts and retail deals that were closer to Samsung than Oppo, Xiaomi and Vivo. This earned Huawei a place just below Apple and Samsung in the global ranks of best telecommunication companies (Cendrowski, 2018). However, according to Wang (2016), Huawei still faces tough competition from Oppo, and the latter is set to be a leading brand in Asia. Oppo is currently the second most popular telecommunication brand in China and its presence in Indonesia means 2,000 job opportunities in Tangerang, Banten, alone. In an August 2015 interview with Techno.id, a technology online magazine, Oppo Electronics' Assistant Human Resources Manager William Khalim said that Oppo's first overseas factory that was opened in Tangerang would hire up to 2,000 local employees in various position levels (Mahardy, 2018). This also means there is growing need for Indonesians who are able to speak Mandarin and have a certain degree of knowledge on Chinese culture.

In the past couple of years, Chinese cars have started to penetrate Indonesian market. Thus far, Wuling and Geely are the market leaders of Indonesia's Chinese car market, but this paragraph will only focus on Wuling. Wuling Motors opened in Indonesia in 2017, and as soon as they opened they built a factory in Cikarang, West Java, that to date has employed up to 3,000 people. In addition to that, Wuling has opened 71 dealerships which cover provinces outside Java such as Aceh and even small cities such as Cianjur in West Java. Until June 2018, Wuling has sold more than 13,000 units in Indonesia and this has cemented their name as one of the top 10 car brands, alongside long-time players Toyota and Daihatsu (Liputan 6, 2018).

All these examples of Chinese companies gaining big sales and popularity in Indonesia means that they are favorable not only because they are cheaper than long-established brands from USA, Europe, Japan and South Korea, but also because in terms of quality they are more or less on par with their American, European, Japanese and South Korean competitors. Anti-ethnic Chinese sentiments that accompanied the 2017 gubernatorial election in which ChineseIndonesian Basuki Tjahaja Purnama was an incumbent running for a second term did not affect the popularity of Chinese brands. The next part of this essay will describe Chinese president Xi Jinping's mega infrastructure project One Belt One 
Road (OBOR) which later changed its name to Belt and Road Initiative (BRI) and how Indonesia's inclusion in this giant global project means a lot to China. To examine this, we will take a look at Chinese universities offering Indonesian language and culture sub-major to students.

\section{Indonesia and the Rest of the World in BRI}

Xi Jinping, China's seventh president, rose to power in March 2013. Throughout his presidency so far, President Xi has won awards within China and overseas for braveness of declaring that China would like to lead the world. This intention he mentioned in a three-hour speech on October 18 2017, and instantly it got the world excited. With US President Donald Trump rising to power only ten months earlier and to date he still does not have a clear policy on Asia Pacific, the global leadership position has been left vacant (Vick \& Campbell, 2018).

In President Xi's first five years in office, he has reasserted the primacy of The Communist Party of China (CPC), fought corruption within government officials and launched a global economic outreach. To his people, he has reasserted in them a heightened sense of nationalism, although he still gets criticized for continuing the tradition of limited speech, keeping the ban against American internet giants such as Instagram, Google and Facebook. He also gets criticized for allegedly trying to make himself president for life, refusing to name a successor after his first term was over. The ban against American internet crazes and his refusal to name a successor crushed the Western hope that he would finally make China a democracy, after his open embrace for market economy that his predecessor Deng Xiaoping had established (Vick \& Campbell, 2018).

Xi's emphasis on soft power diplomacy was already apparent when he was appointed to oversee the 2008 Summer Olympics in Beijing during the presidency of Hu Jintao. The Beijing Summer Olympics was an opportunity for China to show that they were capable of holding a lavish sporting event in an attempt to outgrow its very insular image. As president, $\mathrm{Xi}$ has made significant moves to win the hearts of his people and the world such as the abolishment of torture towards prisoners and the sale of ivories before introducing BRI (Vick \& Campbell, 2018).

BRI, which is worth US\$900 billion, is an attempt to revive The Silk Road that during the medieval time made China one of the most advanced civilizations with its global distribution of silk, ceramics and porcelains. BRI, the new Silk Road, intends to strengthen infrastructure, trade and investment links between China and 65 other countries. These 65 countries collectively account for over 30 per cent of global GDP, 62 per cent of population and 75 per cent of known energy reserves. BRI consists primarily of Silk Road Economic Belt, linking China to Central and South Asia and onward to Europe and New Maritime Silk Road which links China to Southeast Asia, Gulf countries, North Africa and on to Europe (Albert, 2018). 
BRI is important because it aims to substantially reduce trade costs and improve connectivity. For example, shipment by sea of goods from China to any country in Europe takes about 30 days. Shipment by train takes approximately half as long. Therefore, improving the capacity and network of rail infrastructure can radically change average travel time. This radical change will bring a significant cost reduction and impact the total flows of international trade. It will also gradually impact the foreign policy of each individual country involved in the project, as the significant cost reduction brought BRI's rail infrastructure reform will affect fiscal sustainability, cause environmental and social implications. Analysts have even warned that BRI might negatively affect territories (Albert, 2018).

BRI has already been going in full swing in African countries such as Senegal and Kenya to mixed reviews. There has been an official plan since 1971 between African governments and UN Economic Commission for Africa to build TransAfrican Highway. Trans-African Highway is an ambitious network of nine highways traversing the continent for 60,000 kilometers. These nine highways include routes from Dakar in Senegal to Cairo in Egypt $(8,636 \mathrm{~km})$, Lagos in Nigeria to Mombasa in Kenya $(6,260 \mathrm{~km})$ and from Cape Town in South Africa to Cairo $(8,860$ $\mathrm{km}$.) So far, only one of the highways have been completed (Adegoke, 2018).

This is where China comes in. President Xi sees Africa as a market of 54 countries and more than a billion accessible consumers. It was China who helped complete the one afore-mentioned highway, the fifth one which runs from Senegal to Chad for $4,500 \mathrm{~km}$. At the moment, Senegal is working on a US\$140 million industrial park project in a town outskirts of Dakar, Diamniadio. The project was made possible due to investments from Chinese companies (Adegoke, 2018).

Despite the projects and investments, many people are worried about whether or not African governments will be able to pay its debts to China. Take Kenya for example, as of July 2018 the Kenyan government's debts to China has surpassed US $\$ 50$ billion. That is 72 per cent of Kenya's bilateral debts, as China is currently Kenya's biggest lender (Dahir, 2018). Critics have warned that dependency on loans from China can result in African governments letting China meddle with domestic affairs. African countries are not the only ones facing this problem. In Sri Lanka, Beijing has taken over Hambantota Port as the Sri Lankan government could not find funds to finish the port, whose construction began in 2008 . Previously, then President of Sri Lanka Mahinda Rajapaksa granted a 99-year lease of the port to China Merchants Port Holdings in an attempt to continue its construction. The construction, which cost US $\$ 361$ million, was funded mostly by The Exim Importy Bank of China. Later, Colombo found itself unable to pay its Hambantota debts and let Beijing take the port over. Many see this takeover as some kind of "sovereignty loss" (Chaudhury, 2018.) In Laos, a country in Southeast Asia, BRI is currently helping with the construction of a new railway line spanning 414, connecting capital city Vientiane to the China-Laos border. The project, which is scheduled to finish in December 2021, has already garnered a lot of protests for its predominantly Chinese workers (Economic Times, 2018). 
In Indonesia, BRI already has a handful of projects going on. In Bandung, the capital city of West Java, BRI is involved in the construction of 142-km long railway line connecting the city to Jakarta, the country's capital city. The railway, which is BRI's first project in Indonesia and scheduled to open in 2019, has experienced delays related to paperwork issuance and land acquisition. Only 10 per cent of work has been completed as per April 2018. BRI's second project in the country is the nickel-based Morowali Industrial Park in the Central Sulawesi province which by April 2017 had housed ten companies, two of which are Chinese ones (Lamboka, 2017).

Furthermore, the Indonesian Investment Coordinating Board has designated three more provinces for BRI investment purposes: North Sulawesi, North Kalimantan and North Sumatera. Future investment plans include more industrial parks, ports, airports and tourism facilities (Dahir, 2018). However, similar to Laos, since BRI's entry to Indonesia the country has faced issues regarding the overflowing of Chinese workers. According to a Ministry of Manpower data, as of February 2018 there has been a 69.85 per cent rise in the number of foreign workers in Indonesia, going from 74,183 in late 2016 to 126,000 people. Most of these workers are from China. This has caused an outcry within Indonesians saying Chinese workers took over even the most menial jobs from them, and as a result raids against Chinese workers took place in many parts of Indonesia. Minister of Manpower Hanif Dhakiri in an interview with CNN Indonesia on March 32018 said that Indonesia still needed many foreign experts for certain sectors and that The Ministry of Manpower was currently working to made work permit requirements easier for them, but as for middle-lower management jobs down to blue collar ones, he promised that they could be filled by Indonesian nationals. Dhakiri did not explain which sectors still needed foreign experts (Gumelar, 2018).

According to Indonesian President Joko Widodo also in an interview with CNN Indonesia in March 2018, those raids against Chinese workers took place because of the hoaxes that many Chinese workers in Indonesia were illegal. He suggested that a partnership be established between The Ministry of Manpower, The Coordinating Ministry of Economy and The Directorate General of Immigration. In the same CNN Indonesia report, Coordinating Minister of Economy Darmin Nasution said his ministry had eliminated the requirement for a technical recommendation from an institution should the institution feel the need to hire a foreign worker. This only makes it easier for a company to hire foreign workers and it partially explains why there has been a major increase in the number of Chinese workers in Indonesia (Gumelar, 2018).

Despite the Minister of Manpower's promise that middle-lower management jobs down to the menial ones could be filled by Indonesians, fear of many more Chinese workers to come to Indonesia is justified. In May 2018, Lembaga Ilmu Pengetahuan Indonesia (Indonesian Institute of Sciences (LIPI)) published the results of a research on how the rise of Chinese investments correlated with the equally rising number of Chinese workers. It is important to look at how China has 
risen to become the third biggest foreign investor in Indonesia by 2016, rivaled only by Japan and Singapore. At a glance, it seems normal that the number of Chinese works rises with the number of Chinese investments, but China has a policy called Law of The Control of Citizen Exit and Entry that aims to prevent an excess of workers. This policy, which was issued in 1986, is the root for another Chinese policy which rules that every overseas investment must be followed by the employment of Chinese workers. It is because of this policy that many European countries refuse to take part in BRI (Sugianto, 2018). Indeed, another research by C.P.F. Luhulima in his writing "Indonesia dan Tantangan Bagi Integrasi ASEAN" (Indonesia and Challenges for The Integration of ASEAN) shows that BRI is more about China's solution to its excess of workers issue than its desire to became the world's leader (Luhulima, 2017: 347). BRI's many overseas investments will give employment to China's work-age population (age 18-54), which by January 2018 alone had reached about 843 million people out of China's total population of 1.411 billion people (Index Mundi, 2018).

At this point, it can be concluded that Indonesia is important to China not only because Indonesia is a great market with an ever-growing middle class, a good place to invest because of the big work-age population and the relatively easy regulations for foreign workers, but also because it is a link to the rest of the ASEAN countries as well as the greater world. The latter has been in the mindset of the Chinese government since the administration of President Liu Shaoqi which treated Indonesia under Soekarno as an ally through which China could extend its influence beyond the communist world due to Indonesia's non-bloc foreign policy. Later, during the Soeharto presidency, although China had no diplomatic relation with Indonesia from 1967 to 1990 the two countries signed a trade MOU in 1985, this MOU opened the path for China to have trade partnerships with other ASEAN countries. The last part of the essay will pay attention to the rising number of universities in China that offer Indonesian language and culture programs and how this fits into President Xi Jinping's BRI plans regarding Indonesia.

\section{When China Gets to Know Indonesia Deeper}

As already mentioned earlier, until December 2014 there have been 16 universities in China that offer Indonesian language and culture as part of their Southeast Asian Studies program. The 16 universities include Peking University, Shanghai International Studies Universty (SISU), Beijing Foreign Studies Universities, Tianjin Foreign Studies University, Harbin Normal University, Guangxi University of Foreign Languages, Guangxi University of Nationalities, Yunnan University for Minorities, Jilin Huaqiao University of Foreign Studies, Qujing University and Hebei Normal University. A few of said universities have taught Indonesian language and culture for decades. Peking University, for example, has taught Indonesian language and culture since 1949 (C. S. Tjhin, personal communication, September 4, 2018), while SISU started teaching Indonesian language and culture as part of its School of Asian and African Studies in 1952 (Shisu, 2018). A few more did not teach Indonesian language and culture until 
recent years. Harbin Normal University started teaching Indonesian language and culture until 2011 and Hebei Normal University opened their Indonesian language and culture sub-major in 2014. It is noteworthy that Hebei Normal University's Indonesian language and culture sub-major is held in partnership with Ministry of State Security, China's intelligence agency (C. Anwar, personal communication, September 6, 2018).

Although Indonesian language and culture are merely a sub-major in the Southeast Asian Studies programs of the afore-mentioned 16 universities and receive only about 30 per cent of teaching time, it shows that Indonesia is an important partner in the eyes of the Chinese government and CPC elites. Recruitment of students into Southeast Asian Studies programs comes from the government, through scholarships granted to 20 talented yet impoverished high school graduates. These scholarships are usually given at the end of a militarystyle leadership class, which is mandatory for any Chinese national completing 11 th grade. In the middle of their Southeast Asian studies, students are required to spend a year in a Melayu-speaking country (Singapore, Indonesia, Malaysia and Brunei Darussalam.) After a year in any of those countries, students will have to go back to China to defend their theses and graduate. Later, the students will be recruited by CPC as cadres and very often they will be employed by Chinese companies having operations in Melayu-speaking countries including Indonesia (C. Anwar, personal communication, September 6, 2018).

A few universities in China also have partnerships with Indonesian universities. For example, China University of Petroleum in Beijing and University of Science and Technology Beijing (USTB) partner with Institut Teknologi Banding (Bandung Institute of Technology (ITB)) in Bandung, West Java. In November 2012, both Chinese universities signed an MOU with ITB to launch lecturer and student exchange programs for synthetic crude oil development (Berita Satu, 2018). In the field of arts, China Conservatory of Music in Shanghai and Beijing partner with Institut Seni Indonesia (Indonesian Institute of Arts) in Padang Panjang in West Sumatera and Yogyakarta in teaching Indonesian music, with a focus on gamelan and angklung (Shao \& Song, 2018). Angklung has been used in daycare centers in many parts of China, including rural ones, as a means of therapy for small children.

All these universities teaching Indonesian language and culture, as well as having partnerships with Indonesian universities make one wonder how the Chinese government and CPC elites view Indonesia. Former Attache of Education for The Embassy of Indonesia in Beijing, Chaerun Anwar, in an interview on September 6 2018 said that the Chinese government and CPC elites viewed Indonesia as unpredictable. In his own words, Indonesians tend to be late for appointments and the Indonesian Muslims have a habit of saying "insya Allah" (if God wills) as a response if they are asked to do something. "Insya Allah" can be ambiguous as 
foreigners with even the slightest understanding of Indonesia will try to guess what the person saying "insya Allah" means, whether or not they agree with the task asked of them. However, the Chinese government believes that the key to conquering Southeast Asia lies in the conquest of Indonesia, which is geographically the biggest country in the region. Regarding the "unpredictable" nature of Indonesians, still according to Mr Anwar, Hebei Normal University in Hebei province is currently developing a study on the body language of Indonesians (C. Anwar, personal communication, September 6, 2018). This will help Chinese business owners who wish to extend their businesses to Indonesia understand their Indonesian colleagues and target markets.

\section{Conclusion}

From all the above sections we can come the conclusion that Indonesia is very important to China. Long before Indonesia's independence, Chinese dynasties had relations with small kingdoms across Nusantara not only in terms of trade but also culture, as many Chinese women were sent to Nusantara as brides for those kingdoms' princes. After independence during the Soekarno era, China was a significant ally to Indonesia as Indonesia's membership in the Jakarta-PekingMoscow-Pyongyang axis of socialist-communism showed the Western world that Indonesia as a young state was not easily intimidated by them. Likewise, Indonesia was important to China as China was attempting to spread its socialistcommunism ideology and Indonesia had a non-bloc foreign policy under Soekarno. Moving on to the New Order era under President Soeharto, the bilateral relations between Indonesia and China stalled for 23 years from 1967 to 1990, but it did not make the two countries stop having trade relations. In fact, China and Indonesia signed a trade MOU in 1985. The MOU was signed because both countries were trying to attract the USA, Japan and EU markets. Chinese scholars even figured that a trade relation was an important step before re-opening bilateral relations with Indonesia, which would be a stepping stone to relations with other Asia Pacific countries.

The twenty-first century ushered in a new era for Indonesia and China, as President Wahid lifted a 32-year ban against the use of Chinese symbols and characters for Chinese-Indonesians. Mandarin became widely taught at Indonesian schools, and in 2007 Confucius Institute opened in Indonesia in partnership with several Indonesian universities. This brought a better understanding of China within Indonesians and it only made it easier for China, already on its way to become the new superpower, to market its products. Indeed, Chinese brands such as Xiaomi, Huawei and JD have been well-received in Indonesia. 
The next phase is President Xi Jinping's BRI as an attempt to fill in the position of world leader left vacant by US President Donald Trump and Indonesia's role in it. Reflecting on what has happened in African countries where BRI became a "debt trap" after those countries became unable to repay China for the infrastructure it built through the BRI scheme, many experts have warned Indonesia not to be very liberal in accepting Chinese investments. Other than the already on-going outcry about the overflowing of Chinese workers, there are also warnings about a rating downgrade due to the rise of debt levels and deterioration in debt affordability like what happened in Kenya. However, to answer this essay's research question of how Indonesian language and culture sub-majors contribute to BRI, the Indonesian-speaking CPC cadres that are employed in BRI projects in Indonesia can help BRI executors understand Indonesia, its people and their culture. Moreover, the 16 universities that have Indonesian language and culture sub majors are located in Southern China, and Southern China universities are known as the "cradles of diplomats", the graduates of which are employed by the government to give policy advice on Southeast Asian countries. Indeed, a 2017 survey conducted by Perth-USAsia Center in Japan, Indonesia, South Korea, Australia and India showed that for the first time ever, China was seen as the most influential country in the world, replacing USA. A part of this survey even showed that the majority of Indonesian respondents thought Chinese investments were a good thing. In an interview with Prof. Gordon Flake, Chief Executive Officer (CEO) of Perth-USAsia Center, at the launch of "America's Role in Indo-Pacific" report on August 22017 in Jakarta, these Indonesian respondents saw any foreign investments, be they from China, USA or any other country, as incomes for Indonesia that led to the rise of employments for locals as well as economic growth (G. Flake, personal communication, August 2, 2017). This Perth-USAsia Center survey results can be seen as an indirect result of the opening of more Indonesian language and culture sub-majors at Chinese universities to support BRI.

Still, the Indonesian government needs to be careful in accepting basically any foreign investment. Not only China which is famous for its policy of bringing its own workers with each FDI, South Korea has a similar FDI policy that states South Koreans must fill employments down to the middle-management level. This is in contrast with the FDI policy of Japan, where only top-management level employments can be filled by Japanese nationals. Indeed the Indonesian government needs to pay closer attention to, in this case, Chinese companies in terms of employment. An October 2017 report by Elliott Zaagman shows that Huawei has been in hot water in several countries, such as India and South Africa, for a number of violations. Said violations included not giving trainings to local new recruits, giving promotions only to Chinese employees and unceremoniously firing employees through text message (Zaagman, 2018). Now that Indonesia is currently engulfed in the harbinger of what can possibly be a monetary crisis as big as that of the late 1990s (Khor, 2018), one of the things the government must do is ensure that the majority of wok-age Indonesians are gainfully employed. 


\section{References}

$\underline{\text { Books }}$

Faturrachman, D. Apa \& Siapa Alumni Ceko: Profil Mantan Mahasiswa Indonesia Di Ceko Dan Slowakia, Angkatan 1957-1965 Dan Angkatan Sesudahnya. Jakarta: Paguyuban Ex-Pelajar Indonesia Di Ceko-Slowakia (PEPICEK)

Suryadinata, L. Pribumi Indonesians, Chinese Minority and China. London: Heinemann.

Wanandi, Jusuf. Shades of Grey: A Political Memoir of Modern Indonesia 19651998. Jakarta: Equinox.

$\underline{\text { Journals }}$

Davita, G.D. \& Adriani, I. (2016). The Chinese's Government's Cultural Diplomacy Through Partnership Between Confucius Institute and Muslim Universities in Indonesia. AEGIS Journal of International Relations 1(1), 57-59.

Luhulima, C.P.F. (2017). Indonesia dan Tantangan bagi Integrasi ASEAN. Analisis CSIS 46(3), 347.

Sutami, H. (2007). Kekhasan Pengajaran Bahasa Mandarin di Indonesia. Wacana, 9(2), 222-237.

\section{$\underline{\text { Websites }}$}

Adegoke, Y. (July 31 2018). African Countries Know They Need Better Road Networks But Not How To Pay For Them. Quartz Africa. Retrieved August 272018 , from https://qz.com/africa/1343101/1343101/amp/.

Albert, E. (July 12 2017.) China in Africa. Council on Foreign Relations. Retrieved August 27 2018, from https://www.cfr.org/backgrounder/china-africa

Atje R. \& Gaduh, A.B. (September 18 1999). Indonesia-China Economic Relations: An Indonesian Perspective. CSIS Working Paper Series. Retrieved August 29 2018, from http://www.csis.or.id/papers/wps052.

Cendrowski, S. (January 25 2017). How China's Smartphone 'Big Four' Are Fighting For Global Costumers. Fortune. Retrieved August 15 2018, from http://fortune.com/2017/01/24/china-smartphones-oppo-vivo-huawei-xiaomi/.

Dahana, A. \& Herlijanto, J. (October 24 2017). Tionghoa dan Sinologi di Indonesia. Sinologi Indonesia. Retrieved September 11 2018, from https://www.sinologiindonesia.id/tionghoa-dan-sinologi-di-indonesia/. 
Dahir, A.L. (July 10 2018). China Now Owns More Than 70\% of Kenya's Bilateral Debt. Quartz Africa. Retrieved August 28 2018, from https://qz.com/africa/1324618/china-is-kenyas-largest-creditor-with-72-oftotal-bilateral-debt/.

Gumelar, G. (March 3 2018). Jumlah Tenaga Kerja Asing Membludak, Kebanyakan Dari China. CNN Indonesia. Retrieved September 5 2018, from https://www.cnnindonesia.com/ekonomi/20180306201957-92-280945/jumlahtenaga-kerja-asing-membludak-mayoritas-dari-china.

Khor, M. (September 10 2018). Be Ready - Financial Crisis Is Near. The Star. Retrieved September 11 2018, from https://www.thestar.com.my/opinion/columnists/global-trends/2018/09/10/beready-financial-crisis-is-near-with-indonesia-taking-more-drastic-measures-toavert-economic-dis/.

Kuncono, O.S. (August 27 2012). Gus Dur Di Mata Orang Tionghoa Konghucu. Study Park of Confucius. Retrieved August 14 2018, from http://www.spocjournal.com/budaya/85-gus-dur-di-mata-orang-tionghoakhonghucu.html.

Mahardy, D. (August 25 2015). Buka Pabrik, Oppo Sediakan 2.000 Lapangan Kerja di Tangerang. Techno.id. Retrieved August 15 2018, from https://www.techno.id/tech-news/buka-pabrik-oppo-sediakan-2000-lapangankerja-di-tangerang-150825s.html.

Shao, M. \& Song, Z. (November 30 2017). The Indonesian Music Teaching Season Successfully Held by Department of Musicology. On China Conservatory of Music Retrieved September 82018 from http://www.ccmusic.edu.cn/en/?p=1095.

Sugianto, D. (May 9 2018). Hasil Kajian LIPI Terkait Serbuan Tenaga Kerja China. detik.com. Retrieved September 4 2018, from https://finance.detik.com/beritaekonomi-bisnis/d-4012053/hasil-kajian-lipi-terkait-serbuan-tenaga-kerjachina/3.

Wang, Y. (July 15 2016). Apple's China Challenger Is Not Huawei Or Xioami, But Oppo. Forbes. Retrieved 25 2018, from https://www.forbes.com/sites/ywang/2016/07/15/it-is-not-huawei-or-xiaomiapples-latest-china-challenger-is-now-called-oppo/\#48aa58751b25.

Vick, K. \& Campbell, C. (November 30 2017). Xi Jinping: China's Leader Vies for Global. Time. Retrieved August 16 2018, from http://time.com/time-person-ofthe-year-2017-xi-jinping-runner-up/.

Zaagman, E. (October 9 2017). Thinking About Working for A Chinese Company? First, Find Out If It's A 'Lenovo' Or A 'Huawei.' On SupChina.com. Retrieved 
September 12 2018, from https://supchina.com/2017/10/09/thinking-workingchinese-company-first-find-lenovo-huawei/

Setahun Wuling Motors di Indonesia, Ini Pencapaiannya. (July 13 2018). On Liputan 6. Retrieved August 16 2018, from https://www.liputan6.com/otomotif/read/3588414/setahun-wuling-motors-diindonesia-ini-pencapaiannya

Ambassador Xiao Qian Visits Huawei Indonesia. (May 25 2018). On Embassy of The People's Republic of China in Indonesia. Retrieved August 15 2018, from http://id.china-embassy.org/eng/sgdt/t1562928.htm

China's BRI Initiative Hits Roadblock in Seven Countries: Report. (April 15 2018). On The Economic Times. Retrieved August 28 2018, from https://economictimes.indiatimes.com/news/international/world-news/chinasbri-initiative-hits-roadblock-in-7-countries-report/articleshow/63771550.cms.

$\underline{\text { Interview }}$

Anwar, Chairun. Personal interview. September 62018.

Flake, Gordon. Personal interview. August 22017.

Tjhin, Christine Susanna. Personal Interview. September 42018. 